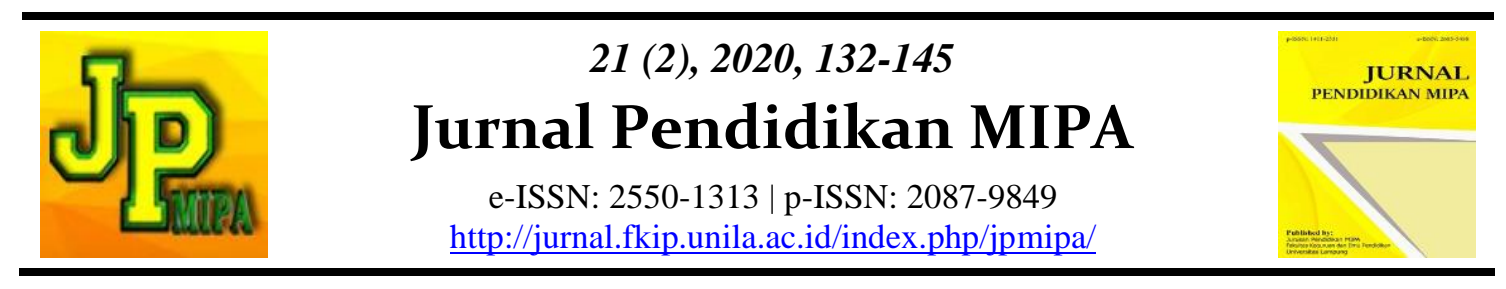

\title{
Dynamic Fluid E-Module with STEM Approach to Stimulate HOTS of High School Students in Distance Learning
}

\author{
Agus Suyatna, Viyanti, Sestika Sari \\ Department of Physics Education, Universitas Lampung, Indonesia
}

\begin{abstract}
Efforts to grow HOTS in high school students are very important to provide for $21^{\text {st }}$ century skills and the demands of the industrial revolution era 4.0. One of these efforts is by providing teaching materials that can stimulate HOTS. This research was aimed to develop a fluid e-module with a valid, effective, and practical STEM approach to stimulate HOTS for high school students. We used the ADDIE R \& D model research method which consists of five stages, which are analysis, design, development, implementation, and evaluation. The developed e-module product was examined for validity, legibility, effectiveness, and practicality tests. The e-module validity test was conducted by five physics learning experts using a Likert scale questionnaire instrument and analyzed using the percentage technique. The legibility test was conducted by five high school students using a Likert scale questionnaire. The practicality test was carried out in senior high schools in Bandar Lampung using a Likert scale questionnaire. The effectiveness test was carried out using the one-group pretest-posttest design. The effectiveness of the dynamic fluid e-module in stimulating HOTS was determined based on the $\mathrm{N}$-gain value and the difference between the pretest and posttest means. The data were analyzed using Wilcoxon Sign Rank test. The results showed that the developed dynamic fluid e-module with the STEM approach was valid, effective, and practical to stimulate HOTS in distance learning in high school.
\end{abstract}

Keywords: e-module, STEM approach, stimulating HOTS, dynamic fluid.

Abstrak: Upaya menumbuhkan HOTS pada siswa SMA sangat penting dilakukan untuk memberikan bekal keterampilan abad 21 dan tuntutan era revolusi industri 4.0. Salah satu upaya tersebut yaitu dengan menyediakan bahan ajar yang dapat menstimulus HOTS. Tujuan penelitian ini yaitu mengembangkan e-modul fluida dengan pendekatan STEM yang valid, efektif, dan praktis untuk menstimulus HOTS pada pembelajaran fluida di SMA. Metode penelitian yang digunakan adalah $R \& D$ model ADDIE yang terdiri dari lima tahap yaitu analysis, design, development, implementation, dan evaluation. Produk e-modul hasil pengembangan diuji validasi, uji keterbacaan, uji efektivitas, dan uji kepraktisan. Uji validasi e-modul dilakukan oleh lima orang ahli pembelajaran fisika menggunakan instrumen kuesioner skala Likert dan dianalisis menggunakan teknik persentase. Uji keterbacaan dilakukan oleh lima orang siswa SMA menggunakan kuesioner skala likert. Uji kepraktisan dilakukan di SMA yang ada di Bandar Lampung menggunakan kuesioner skala likert. Uji efektivitas dilakukan menggunakan one group pretest posttest design. Efektivitas e-modul fluida dinamis dalam menstimulus HOTS ditentukan berdasarkan nilai $N$-gain dan adanya perbedaan rata-rata pretest dengan posttest. Analisis data dilakukan menggunakan uji Wilcoxon Sign Rank. Hasil penelitian menunjukkan emodul fluida dinamis dengan pendekatan STEM hasil pengembangan, valid, efektif, dan praktis untuk menstimulus HOTS pada pembelajaran jarak jauh di SMA.

Kata kunci: e-modul, pendekatan STEM, menstimulus HOTS, fluida dinamis.

Agus Suyatna et al.

Email: asuyatna@yahoo.com
DOI: http://dx.doi.org/10.23960/jpmipa/v21i2.pp132-145

Received: 11 November 2020

Accepted: 08 December 2020 


\section{INTRODUCTION}

Regarding the 21 st century and the era of the industrial revolution 4.0 demands, every individual is required to have critical thinking, creative thinking, problem solving, communication, and collaboration skills. This demand has implications for student learning in schools. One of the strategies to prepare students in this era is practicing student's higher-order thinking skills (HOTS) in daily learning at school. Many ways are needed to optimize the HOTS stimulus in the learning process in schools. The process of training HOTS can be started by practicing critical thinking skills and habits, researching, solving problems, making decisions. Students need to be given a higherorder thinking stimulus by showing various contextual phenomena that are challenging to identify, analyze, evaluate, so that they can grow ideas to create or create. The process of promoting thinking skills will encourage students' conceptual understanding (Osborne \& Patterson, 2011). The scientific approach is a way to develope skills in the 21 st century (BSNP, 2010). Learning activities that are emphasized on this have implications for learning activities where students do not only acquire scientific knowledge but rather contain scientific knowledge that can practice thinking skills.

Teachers had a difficulty in providing empirical experience related to fluid material, because of the limited information on how fluid learning can be visualized and learned with a scientific approach. Fluid learning had been directed at memorizing only which results in a lack of mastery of science material as a whole. Teachers had doubts about getting out of traditional learning as a result: (1) the teacher loses control of the class, (2) the teacher needs a lot of time to have a discussion (very lacking content), and (3) skepticism about whether students can learn on their own (Knight, Wise, \& Southard, 2013). So far, science learning standards have not been able to predict and explain the scientific phenomena of an object (Loverude, Kautz, \& Heron, 2003). Scientific phenomena can be applied to many scientific and engineering problems. Science is a science that is easy to visualize, and emphasizes quantitative variables that test the implications of a model (Saleta, Tobia, \& Gil, 2005). Science is the core of science and is related to the ability to think scientifically (Bao, Fang, Cai, Wang, Yang, Cui, ... \& Luo, 2009). Fluid learning needs to involve observing various fluid science phenomena in nature, their use in technology, and their development in various technological products, as well as formulations that apply to fluids. Fluid learning involving Science, Technology, Engineering, Mathematics (STEM) content has the potential to stimulate HOTS.

The development of electronic book technology encourages a combination of print and computer technology in learning activities. The presentation of the module is not only a print presentation but is now being developed in electronic form. The electronic module is a form of presenting independent teaching materials that are arranged systematically, into the smallest learning unit, achieving certain learning objectives, which are presented in electronic form in which there are animations, audio, navigation that make users more interactive in learning (Nurmayanti, Bakri, \& Budi, 2015). Learning using interactive electronic modules involves audio-visual displays, sound, movies, and others (Sugianto, Abdullah, Elvyanti, \& Muladi, 2013). So that learning becomes more interesting, the content of the module is easier to understand because the content becomes more real. Electronic media accessed by students has different benefits and characteristics. If viewed from the benefits of electronic media itself, it can make the learning process more interesting, interactive, can be done anytime, anywhere (Nurmayanti, Bakri, \& Budi, 2015), so that it can improve the quality of the learning process. 
Electronic modules, like printed module systematics, can be used as independent learning resources that can help students improve their competence or understanding. Emodule can also be used anywhere, making it more practical to carry anywhere. The characteristics of the e-module are an amalgamation of print and computer media, so emodules can present information in a structured, attractive manner and have a high level of interactivity (Sugianto, Abdullah, Elvyanti, \& Muladi, 2013). Besides, the learning process no longer depends on the instructor as the only source of information, resulting in the creation of interactive and learner-centered learning as expected in the 2013 curriculum. Electronic modules can also be used to improve the conceptual understanding of the material presented by educators. In addition, the existence of an electronic module can save the use of paper that is continuously produced for printing learning books. This is one of the Go Green movements to save trees as raw material for papermaking (Ghaliyah, Bakri, \& Siswoyo, 2015).

The term STEM had been known since the 1990s. At that time the NSF (National Science Foundation) office in the United States used the term SMET but because the pronunciation was almost the same as "smut", at that time SMET was changed to STEM until today (Syukri, Halim , \& Meerah, 2013). STEM education is defined as an integrated learning approach as a collaboration of four scientific disciplines, so that learning using the STEM approach is expected to be able to develop student skills in the era of the industrial revolution 4.0 (Arslan, Cigdemoglu, \& Moseley, 2012).

The four disciplines in the STEM learning process are: a. Science is a scientific discipline that is related to natural sciences; $b$. Technology is one of the disciplines that collaborate technology and science, for example in modern technology that is made today and is developing very rapidly; c. Engineering disciplines that operate and design with structured procedures that can solve problems; d. Mathematics of this discipline can increase innovation from technology and can produce an exact language of science in science, technology and engineering disciplines (Task Force STEM, 2014).

STEM means teaching and learning related to the fields of Science, Technology, Engineering, and Mathematics (Gonzalez \& Kuenzi, 2012). Furthermore, Hannover Research (2011) states that STEM has an objective, namely an effort to demonstrate holistic knowledge between STEM subjects. The integration of the learning system with the STEM approach can be said to be successful if all aspects of STEM are contained in each learning process for each subject. STEM education is not only an integrated learning approach separately but also can develop mathematics, technology, scientific approaches, and techniques so that it can solve contextual problems in everyday life.

Higher-order thinking skills or HOTS are a broad use of the mind to find new challenges. Higher order thinking skills require a person to apply new information or previous knowledge and manipulate information to reach possible answers in new situations. Higher-order thinking processes require students to get information or ideas in certain ways that can provide them with new knowledge and understanding. Highorder thinking skills are thinking at the reasoning stage in order to be able to understand information and lessons at school, but also to be able to use the knowled ge gained in everyday life (Annuuru, Johan, \& Ali, 2017). Fluid material is closely related to everyday life. The phenomenon of fluids is often found in various technological tools that are often found in everyday life. This subject matter can be carried out in schools with minimal laboratory equipment (Risca \& Nadi, 2014), but with information technology assistance. Learning fluid material with the STEM approach and assisted by information technology has a high potential to stimulate student HOTS. 
Interdisciplinary integration can begin with real-world problems. Combining crosscurricular content with critical thinking, problem-solving skills, and knowledge to reach conclusions (Wang, Moore, Roehrig, \& Park, 2011). Higher order thinking skills are central to science practice and must be at the core of science, which can guide students to understand the epistemology of the scientific method (Simon \& Richardson, 2009). Through higher-order thinking skills, it provides students with phenomena and demonstrated evidence down to thought-intensive concepts (Howe, McWilliams, \& Cross, 2005). Higher order thinking skills are tools that play an important role in the growth of scientific knowledge.

Efforts to develop HOTS in high school students are very important to provide for the skills of the 21 st century and the demands of the industrial revolution era 4.0. One of these efforts is by providing teaching materials that can stimulate HOTS. Based on the description above, science learning using the STEM approach would be suitable to stimulate HOTS, but it needs to be facilitated with teaching materials that can be used independently and the characteristics of students in this millennial century. The results of interviews with several high school physics teachers, obtained information that teachers have difficulty applying the scientific approach that stimulates HOTS in fluid learning because there is very little time and there are no learning resources that can be used independently. Therefore, it is necessary to develop a fluid learning resource using the STEM approach, which is designed to be used independently and can stimulate HOTS, namely in the form of e-modules. The purpose of this study is to develop a dynamic fluid e-module with a valid, effective, and practical STEM approach to stimulate HOTS in high school distance learning.

\section{METHOD}

This research used a Research and Development (R\&D) method design. The development procedure that was carried out adapted ADDIE model which consists of five stages, they were: analysis, design, development, implementation, and evaluation.

\section{Analysis}

The analysis stage contained the activities of the need assessment, which identified the need for e-module fluid material for physics teachers and eleventh graders. Need assessment identification included content, form, characteristics, design, and systematics. The data collection instrument used a closed questionnaire that was distributed to physics education lecturers, physics teachers, and high school students in Lampung Province. Data were collected using a web-based survey through google form. Respondents were taken based on willingness to fill out a google form. Data analysis from the questionnaire results was described in terms of a percentage, then interpreted qualitatively.

\section{Design}

This stage was the process of designing the content, systematics, characteristics, and platform for making e-modules. The stages of activities start from determining competency achievement indicators for basic competencies regarding fluids, compiling study materials, compiling learning materials, designing e-module characteristics and systematics, compiling e-module story-boards, determining application programs to build e-modules, compiling instruments HOTS test. The characteristics of the e-module were determined based on the results of the needs analysis. 


\section{Development}

In this stage all the design results were realized into the product that is ready to be implemented. The product was developed in the form of a fluid interactive e-module arranged systematically in accordance with the STEM approach and aims to stimulate HOTS. The entire product (Draft I) was tested for the validity by 3 experts in physics education and 3 physics teachers. The validity process was carried out as in the flowchart of Figure 2. After the product was valid, then the legibility and ease of use test were carried out by six students of class eleventh grade students. The instrument used to examine the validity, legibility and ease of use were questionnaires. Data analysis from the questionnaire results were described in terms of a percentage, then interpreted qualitatively.

\section{Implementation}

This implementation stage was the e-module trial phase that has passed the validation, legibility, and ease of use tests in the actual class. Field trials were conducted using a quasi-experimental research design, namely one group pretest posttest design.

The experimental class were given fluid learning assisted by the developed emodule. The e-module was given to students to be used for independent learning and facilitated by the teacher online. They were asked to study the entire content of the emodule individually. The pretest was carried out before students receive the e-module and the posttest was carried out after the students learn independently using the e-module. The test instrument contained HOTS questions and was carried out online.

\section{Evaluation}

The evaluation stage was carried out to determine the feasibility of a product developed. In the evaluation phase, the practicality and effectiveness of the developed emodule will be tested. Practicality was measured using a questionnaire. The questionnaire was given to students who were the test subjects in this study. Data analysis from the questionnaire results is described in terms of a percentage, then interpreted qualitatively.

The effectiveness of the e-module was measured using a test on the cognitive aspects of the HOTS level for students. The effect of using the e-module on the development results is determined based on the significant increase in the average HOTS of students before and after using e-module and the $\mathrm{N}$-gain value. Tests were carried out using the non-parametric Wilcoxon Sign Rank statistical test.

\section{RESULT AND DISCUSSION}

\section{Description of dynamic fluid e-module}

The developed e-module was designed to stimulate the ability to analyze, evaluate, and create dynamic fluid materials and is designed using the STEM approach. Therefore, each learning activity is designed to contain STEM components in dynamic fluid material. For example, in Learning Activity 4 which aims to stimulate the ability to evaluate pitot tube technology, the STEM components are designed as follows.

1) Science: the narrative of the continuity equation and the law of Bernoulli related to the pitot tube. Measuring the value of pressure by observing the change in height experienced by the fluid and the principle of velocity based on the flow of the pitot tube.

2) Technology: the visualization of several types of pitot tubes consisting of simple 
pitot tubes, static source and pitot-static tubes along with audiolization as an introduction.

3) Engineering: the narrative that contains the workings of the application of the pitot tube by analyzing parts of the pitot tube

4) Mathematics: The formulation of quantities and units involved in the equation for the velocity of fluid flow regarding the pitot tube and its mathematical derivation.

Learning activities designed in the e-module were in the form of presenting fluid phenomena through video, discussion of STEM component studies on the phenomena shown, conducting experimental simulations, designing tasks, doing interactive formative tests, and reflecting. Learning activities facilitated students to analyze, evaluate, and create science, technology, engineering, and mathematical formulations contained in fluid material. In addition to prioritizing the content of the material, this e-module also prioritizes its appearance. The aim was to make students interested in using e-module learning resources. Through the e-module students can learn in a fun way and acquire new, interesting skills and not only contain interactive buttons but also contain simple materials and videos with the hope of being able to provide learning challenges, motivate, and stimulate student HOTS. The e-module design chart is shown in Figure 1.

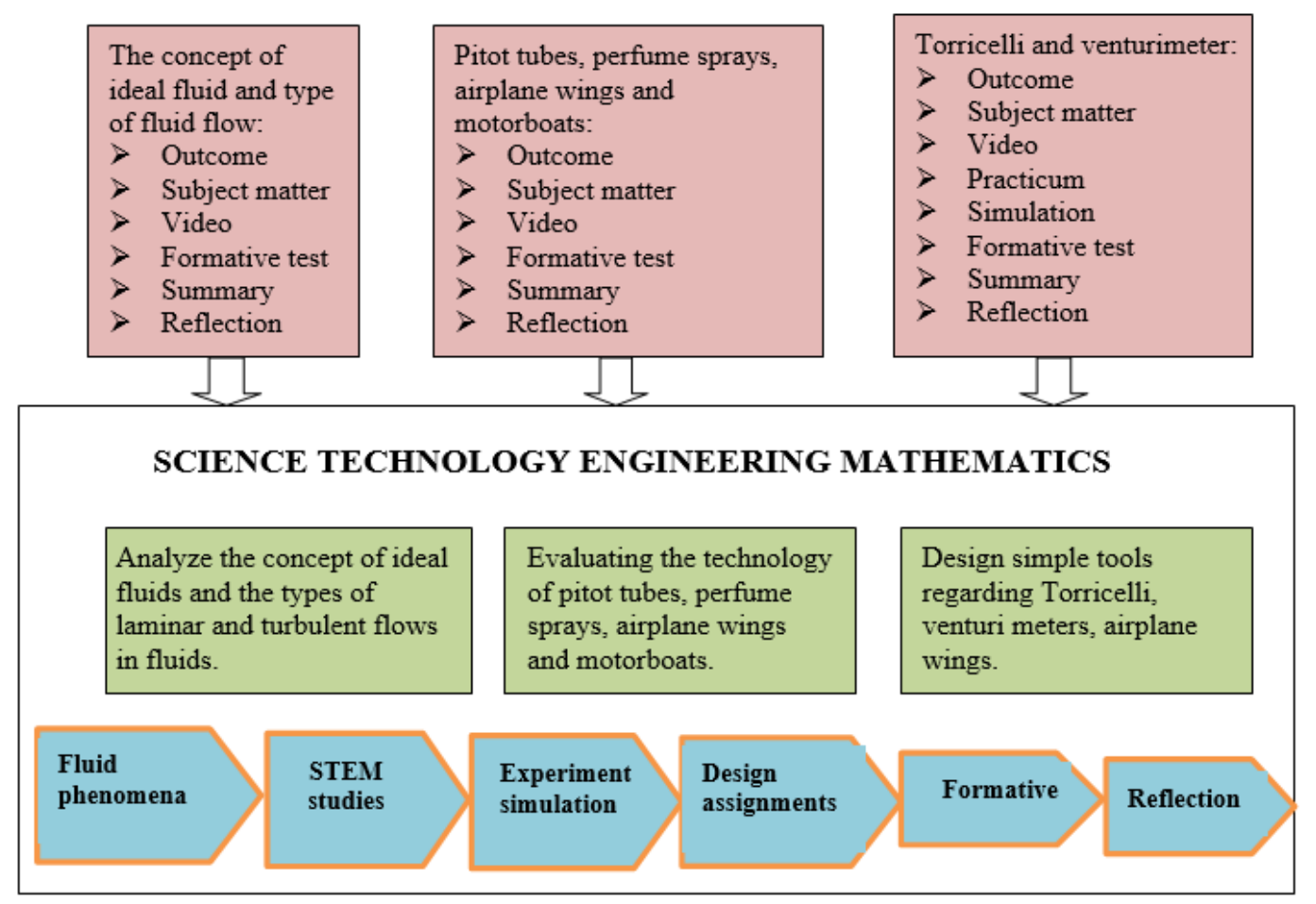

Figure 1. Dynamic fluid e-module design diagram

\section{Validity test result}

The developed e-module was examined for the validity by three experts in the field of physics education and two teachers with master qualifications in the field of physics education. The results of expert validation in the design and language aspects are presented in Table 1. Based on the assessment of the five validators, the average score was 4.36 or $87.2 \%$. The score indicated that the design and language used in the e-module 
is very feasible to be used. The e-module that meet all quality aspects such as layout, legibility, clarity, convenience, attractiveness, feasibility, completeness will certainly help students carry out learning independently.

Table 1. Recapitulation of expert validity test results for design and language aspects

\begin{tabular}{clcc}
\hline No & \multicolumn{1}{c}{ Rated aspect } & $\begin{array}{c}\text { Average } \\
\text { score }\end{array}$ & $\begin{array}{c}\text { \% } \\
\text { Average } \\
\text { score }\end{array}$ \\
\hline $1 \quad \begin{array}{l}\text { The suitability of the layout, composition of text and } \\
\text { images used on the cover }\end{array}$ & 4.40 & $88 \%$ \\
$2 \quad \begin{array}{l}\text { Readability, use of fonts, layout and arrangement of } \\
\text { images, videos, links to other learning resources }\end{array}$ & 4.20 & $84 \%$ \\
$3 \quad \begin{array}{l}\text { Clarity, suitability of shape and size, color, attractiveness, } \\
\text { images/animation/simulation/video }\end{array}$ & 4.36 & $87 \%$ \\
$4 \quad \begin{array}{l}\text { Ease and functionality of navigation buttons/symbols/links } \\
5\end{array}$ & 4.47 & $89 \%$ \\
$\begin{array}{l}\text { Suitability of the form plate used to construct formative } \\
\text { tests. }\end{array}$ & 4.80 & $94 \%$ \\
$6 \quad \begin{array}{l}\text { Attractiveness and appropriateness of the HOTS stimulus } \\
\text { used in formative evaluation. }\end{array}$ & 4.00 & $80 \%$ \\
$\quad \begin{array}{l}\text { The suitability of the feedback mechanism, filling in and } \\
\text { collecting the results of reflections and assignments }\end{array}$ & 4.33 & $87 \%$ \\
$8 \quad \begin{array}{l}\text { Completeness of the contents of the e-module (includes } \\
\text { complete components: cover, introduction, table of } \\
\text { contents, competencies, manuals for use, learning } \\
\text { activities, assignments, formative tests, reflections, } \\
\text { summaries, summative tests, and bibliography). }\end{array}$ & 4.40 & $88 \%$ \\
\hline $\begin{array}{l}\text { Conformity, clarity, ease of understanding the language } \\
\text { used in the e-module. }\end{array}$ & 4.28 & $85 \%$ \\
\hline Final Average Score & 4.36 & $87.2 \%$ \\
\hline
\end{tabular}

Similar to the validity of the e-module design aspects, the content/material aspects of the e-module was also validated by the same five validators. The results of the content/material validation were presented in Table 2. Based on the validator's assessment, the average score was 4.10 or $82.0 \%$. The result showed that the content/material and learning activities prepared in the e-module are very suitable to stimulate student HOTS. Selection of the right material, both in terms of content and form of teaching materials, such as video, simulation, pictures, graphics, will greatly help students understand the teaching material. The completeness of the STEM components in study materials or teaching materials, can stimulate students to think critically. Students here are required to connect each STEM component to build a comprehensive understanding.

Table 2. Recapitulation of content validity test results on content/material aspects

\begin{tabular}{clcc}
\hline No & Rated aspect & $\begin{array}{c}\text { Average } \\
\text { score }\end{array}$ & $\begin{array}{c}\% \\
\text { Average } \\
\text { score }\end{array}$ \\
\hline $1 \quad \begin{array}{l}\text { The suitability of indicators and learning objectives with core } \\
\text { competencies and basic competencies based on the 2013 } \\
\text { curriculum }\end{array}$ & 4.5 & $90 \%$ \\
\hline
\end{tabular}




\begin{tabular}{|c|c|c|c|}
\hline No & Rated aspect & $\begin{array}{l}\text { Average } \\
\text { score }\end{array}$ & $\begin{array}{c}\% \\
\text { Average } \\
\text { score }\end{array}$ \\
\hline 2 & $\begin{array}{l}\text { Suitability, completeness, systematics, and clarity of learning } \\
\text { material in every learning activity with learning objectives }\end{array}$ & 4.2 & $84 \%$ \\
\hline 3 & Conformity of the principles and theories used with physics & 4.8 & $96 \%$ \\
\hline 4 & $\begin{array}{l}\text { Suitability of material selection with the level of student } \\
\text { education }\end{array}$ & 4.2 & $84 \%$ \\
\hline 5 & Completeness of STEM components in learning materials & 4.6 & $92 \%$ \\
\hline 6 & $\begin{array}{l}\text { The suitability and accuracy of images/simulations/videos in } \\
\text { clarifying learning }\end{array}$ & 4.0 & $80 \%$ \\
\hline 7 & $\begin{array}{l}\text { The accuracy of the material explanation in the } \\
\text { image/simulation /video in describing physical phenomena or } \\
\text { facts }\end{array}$ & 3.8 & $76 \%$ \\
\hline 8 & $\begin{array}{l}\text { The suitability of the material/video/simulation links } \\
\text { presented to support/enrich the core material }\end{array}$ & 3.8 & $76 \%$ \\
\hline 9 & $\begin{array}{l}\text { The suitability of the combination of learning materials with } \\
\text { pictures/simulations/videos }\end{array}$ & 3.8 & $76 \%$ \\
\hline 10 & Suitability and attractiveness of the HOTS question stimulus & 3.9 & $78 \%$ \\
\hline 11 & $\begin{array}{l}\text { The suitability of questions to measure the ability to analyze, } \\
\text { evaluate, create }\end{array}$ & 3.8 & $76 \%$ \\
\hline 12 & $\begin{array}{l}\text { The assignments presented in the e-module can develop } \\
\text { creativity and foster collaboration between students }\end{array}$ & 4.0 & $80 \%$ \\
\hline \multicolumn{2}{|c|}{ Final Average Score } & 4.10 & $82.0 \%$ \\
\hline
\end{tabular}

According to the validators, overall the contents quality of the e-module is in the high category, however, there was still something that needs to be improved, especially in the formative test section so that it more stimulates students. There were still sentences that were not quite right in interpreting the fluid flow rate. Based on this assessment, improvements were made according to the validator's suggestions.

\section{Legibility test results}

The legibility 1-1 test of the e-module product was carried out by five high school students who were prospective e-module users outside the test subject. This test was intended to ensure that the e-module is easy to operate, can be used as a learning resource, is interesting, and helps students to understand dynamic fluid study materials. The results of the legibility test obtained an average score of 4.7 which means that all students strongly agree with the contents of all statements regarding the legibility of e-modules.

Table 3. Recapitulation of e-module readability test results by students

\begin{tabular}{clcc}
\hline No & \multicolumn{1}{c}{ Item } & Average & Description \\
\hline 1 & $\begin{array}{l}\text { Variations in the use of fonts (size, shape, type and } \\
\text { color) make e-modules interesting to learn }\end{array}$ & 4.8 & Strongly agree \\
2 & $\begin{array}{l}\text { Lay-out design (text and image layout) makes e-module } \\
\text { easy to understand }\end{array}$ & 4.4 & Strongly agree \\
3 & $\begin{array}{l}\text { The use of language in the e-module is appropriate so that } \\
\text { it does not cause double meanings } \\
\text { The use of images/simulations/videos makes e-modul } \\
\text { more interesting }\end{array}$ & 4.8 & Strongly agree \\
\hline
\end{tabular}




\begin{tabular}{clcc}
\hline 5 & $\begin{array}{l}\text { The use of language in online discussion forums is clear } \\
\text { and logical to make problems easy to understand }\end{array}$ & 4.4 & Strongly agree \\
6 & $\begin{array}{l}\text { The use of language in evaluation questions is clear and } \\
\text { logical }\end{array}$ & 4.6 & Strongly agree \\
7 & $\begin{array}{l}\text { Reflection questions can be understood and easily } \\
\text { answered }\end{array}$ & 5.0 & Strongly agree \\
$8 \quad \begin{array}{l}\text { The e-module's overall format encourages higher-order } \\
\text { thinking }\end{array}$ & 4.8 & Strongly agree \\
$9 \quad \begin{array}{l}\text { Instructions/commands/guides can make it easier for } \\
\text { students to operate the e-module }\end{array}$ & 4.6 & Strongly agree \\
$10 \quad \begin{array}{l}\text { The presentation flow makes it easy for the e-module to } \\
\text { understand }\end{array}$ & 4.8 & Strongly agree \\
$11 \quad \begin{array}{l}\text { The content scope (images, animations, simulations, and } \\
\text { videos) makes e-module easy to learn }\end{array}$ & 4.8 & Strongly agree \\
12 & The content clarity makes the e-module easy to learn & 4.8 & Strongly agree \\
\hline Average & 4.7 & Strongly agree \\
\hline
\end{tabular}

The real users of this e-module are high school students. Therefore, information about the legibility test results according to student potential users is very important. According to students, this e-module has an appropriate design, understandable language, attractive images/simulations/videos, easy to operate, easy to learn content coverage, presentation flow that is easy to understand.

\section{Field test}

The implementation was carried out by the developer for three weeks to achieve all existing learning indicators in dynamic fluid material. One of the impacts of the Covid19 pandemic in learning was the reduced learning hours carried out by students. The reduction in learning hours was very large, even more than $50 \%$ from the previous learning hours, which should have been 45 minutes to 20 minutes for each meeting. In fact, what should have been held twice a week was only once.

Based on the regulations of the Ministry of Education and Culture of the Republic of Indonesia to implement online learning for areas with red zones, the implementation stage was carried out online assisting by the learning media. The media used in this implementation were WhatsApp, Zoom, and Email. This implementation was monitored by the physics teacher who was responsible for the physics subject.

The first learning meeting was held for 2 lesson hours within 40 minutes. Utilizing time effectively and efficiently was certainly a big obstacle in learning with this new system. Before the implementation begins, the developer first provides a link for students to download the e-module on their respective computers along with a guide sheet for accessing the dynamic fluid e-module. The first implementation begins with the zoom meeting application, where students are expected to access the link provided by the developer. The first ten minutes the developer checks the attendance of students and provides directions on the learning objectives that must be achieved at the meeting. Then 20 minutes are used to direct and give students time to access the E-Module given before the first lesson begins.

The limitations of different facilities for each student resulted in not all students being able to access the zoom link that was shared, there were at least 4-5 students per meeting who confirmed through the Group Whatsapp (WAG) that they were constrained by signals when going to learn. However, this did not prevent them from completing the 
lesson because the e-module provided was offline, so students could access it even though the signal was not good.

The second day of implementation was carried out through zoom with the first 10 minutes of students filling in the attendance list first on the google form link. After that, the instructor guided students to open the e-module on the Learning Activity sheet 5 with the aim of evaluating the working principles of airplane and sailboat technology. It should be stated that not all learning activities in the module were tested. This was because of a very limited time given for testing. Some students gave opinions about the learning being carried out, this was evidenced by documentation in the form of a video record zoom meeting when the lesson was carried out. At the end of the lesson, students were given a project to design an airplane wing with the forces that influence it, this project was completed by students in groups which were then presented through video call records of each group which were collected via e-mail within one week. Before the second meeting was closed, students were asked to fill in the reflection provided via the google form link on the e-module.

The last day of the implementation contained the activities that asked students to collect videos of projects they have finished. Through the zoom meeting, students were guided to fill in the attendance list. Then students were asked to complete the summative evaluation (posttest) contained in the e-module. This summative evaluation was connected via google form which will produce a classification from the effectiveness test of the product being developed. After the summative evaluation has been carried out, students are directed to fill in the google form that has been distributed through the WAG regarding the response of the product and the learning carried out during the implementation period which will result in a classification from the practicality test of the product being developed by the developer. The effectiveness and practicality test was completed by 34 students. Even though there were many obstacles faced when implementing this, it did not reduce the enthusiasm of students who were persistent in learning and high curiosity. Therefore, the online implementation runned well and was completed on time.

The field test produced e-module practicality data (Table 4) which includes four aspects of student response, namely effectiveness, attractiveness, efficiency, and ease of operation, with an average score of 4.62 or $93 \%$ of the practicality aspects have been achieved. The data on the results of the e-module effectiveness test were obtained from the learning outcomes test at the HOTS level. The test results as well as the test results for the difference between the pre-test and the post-test mean and the n-gain acquisition are presented in Table 5. The average difference test was carried out using the nonparametric Wilcoxon Sign Rank statistic, because the distribution of the post-test data was not normal.

Table 4. Recapitulation of e-module practicality test results

\begin{tabular}{llcc}
\hline No. & \multicolumn{1}{c}{ Observed Aspects } & Average Score & \% Average Score \\
\hline 1 & Effectiveness & 4.65 & $92 \%$ \\
2 & Attractiveness & 4.82 & $96 \%$ \\
3 & Efficiency & 4.78 & $95 \%$ \\
4 & Ease of use & 4.21 & $84 \%$ \\
\hline Final Average Score & 4.62 & $93 \%$ \\
\hline
\end{tabular}

The non-parametric Wilcoxon Sign Rank test results obtained p value $<0.05$, meaning that there was a significant difference between the pre-test and the post-test mean 
at the $95 \%$ confidence level. In other words, the e-module developed was effective for increasing student HOTS in dynamic fluid material. The magnitude of the increase in learning outcomes could be seen in the average n-gain acquisition, which was 0.70 . This value was included in the medium category (Hake, 2002). Based on the acquisition of an average n-gain score, it can be concluded that e-module was effective in stimulating HOTS.

Table 5. Recapitulation of the e-module effectiveness test and mean difference test $(\mathrm{n}=34)$

\begin{tabular}{llccccc}
\hline No. & Parameter & Pre-test & Post-test & Gain & n-gain & p \\
\hline 1 & Mean & 60.3 & 87.9 & 27.6 & 0.70 & 0.000 \\
2 & Maximum score & 80 & 100 & 60 & 1.00 & \\
3 & Minimum score & 40 & 60 & 0 & 0.00 & \\
4 & Standard deviation & 11.41 & 12.74 & 17.07 & 0.37 & \\
\hline
\end{tabular}

The findings showed that e-module was effective in stimulating student HOTS because the learning activities and contents of the e-module encourage students to think with a STEM approach. For example in Learning Activity 5, the first e-module displays a video of the state of an airplane wing when the plane takes off and landing (technology component) and simulates airflow around an airplane wing (Science component). Then ask students to think about why a very heavy airplane can fly, with a focus on the construction of the wing and the velocity of air flow above and below the wing of the aircraft (HOTS stimulus). Furthermore, it explains the equations of continuity and Bernoulli's law related to aircraft wing technology in a narrative. The mathematical formulation of the equation for lift regarding the wing of an airplane and its mathematical derivation is discussed (mathematical component). After that the students in groups were given a project assignment to design an airplane wing shape so that it had a large lift. This assignment was presented by students via video. At the end, students are asked to reflect on their learning experiences. Student reflection was assisted by using four questions submitted via google form. The following is an example of the results of student reflection.

Q1: What are some of your experiences after completing Learning Activity 5?

A1: It turns out that an airplane can fly not only from the engine on the plane but also from the wing shape which causes an upward thrust.

A2: What I just understood is that the shape of an airplane wing serves to raise / fly aircraft other than the engine on the plane.

Q2: What additional information do you need to complete this material, thereby increasing your understanding of this material?

A1: Can find out about the surrounding technology using dynamic fluid systems.

A2: Gaining knowledge about the aerodynamic shape of the aircraft

Q3: What benefits do you get after studying this material in your daily life?

A1: Increase the velocity of the fluid by decreasing the flow pressure, velocity and pressure inversely.

A2: Knowing what causes an airplane with such a large mass but capable of flying.

Q4: What solutions do you offer in problems regarding dynamic fluids, especially the environment around you? 
A1: If an airplane is to fly properly, the wings must be designed according to Bernoulli's Law ..

A2: When watering plants with a short hose, the outlet of the hose is narrowed so that the water distance is long

Self-reflection activities fostered students' abilities to identify new experiences obtained during the learning process, find out additional information needed to complement learning outcomes and the benefits obtained from studying a material, and can apply their knowledge/skills to solve or provide solutions to problems in everyday life -day. According to Oktaria (2015), self-reflection ability can make learners lifelong.

The effectiveness of the e-module developed is in line with other research findings. E-modules can make the learning process more interesting, interactive, can be done anytime and anywhere and can improve the quality of learning (Nurmayanti, Bakri, \& Budi, 2015). Through video and animation, it can make it easier for students to understand abstract physics concepts and can be used independently. Virtual simulations on emodules are at least as effective as real laboratories. It can maximize interactivity that motivates students to become active thinkers (Tatli \& Ayas, 2013). The results of the research by Suyatna, Maulina, Rakhmawati, \& Khasanah (2018) show that interactive electronic books are more effective in teaching physics than printed books. This is possible because interactive electronic books can be equipped with videos showing physical phenomena as well as virtual laboratory simulations. Videos can reduce abstraction in physics learning and show real phenomena. Virtual simulations allow students to carry out experiments independently, without having to be in the laboratory. Practical simulations are suitable media to help students learn independently and give them the opportunity to explore teaching materials (Karanggulimu, Sudjito, \& Noviandini, 2017) and building process skills (Setiadi \& Muflika, 2012).

\section{CONCLUSION}

Dynamic fluid e-module which contains all STEM components with an arrangement of learning activities to visualize fluid phenomena, discussion of STEM components on fluid phenomena, practicum simulations for deeper exploration, assignments to make designs/projects, formative tests, and self-reflection, was valid to stimulate student HOTS High school. Students who learn distance using developed emodule products experience an increase in HOTS in the moderate category. Selfreflection activities can train students to identify new experiences obtained, additional information needed to complement learning outcomes, the benefits obtained from studying a material, and provide solutions to problems in everyday life that can be obtained from learning outcomes.

\section{ACKNOWLEDGMENTS}

Thank you to the Directorate of Research and Community Service (DRPM Ristekdikti) who have funded this research through the PTM scheme. Thanks are also conveyed to the Lampung University Research and Community Service Institute (LPPM Unila) which has facilitated the research. 


\section{REFERENCES}

Annuuru, T. A., Johan, R. C., \& Ali, M. (2017). Peningkatan Kemampuan Berpikir Tingkat Tinggi dalam Pelajaran Ilmu Pengetahuan Alam Peserta Didik Sekolah Dasar Melalui Model Pembelajaran Treffinger [Increasing Higher Level Thinking Ability in Natural Science Lessons for Elementary School Students through the Treffinger Learning Model]. Educational Technologia, 1(2). 136-144

Arslan, H. O., Cigdemoglu, C., \& Moseley, C. (2012). A three-tier diagnostic test to assess pre-service teachers' misconceptions about global warming, greenhouse effect, ozone layer depletion, and acid rain. International Journal of Science Education, 34(11), 1667-1686.

Bao, L., Fang, K., Cai, T., Wang, J., Yang, L., Cui, L., ... \& Luo, Y. (2009). Learning of content knowledge and development of scientific reasoning ability: A cross culture comparison. American Journal of Physics, 77(12), 1118-1123

BSNP. (2010). Pengembangan Paradigma Pendidikan Nasional Abad XXI [Development of the XXI Century National Education Paradigm]. (online). Retrived from http://www.bsnp-indonesia.org/id/wp-content/uploads/2012/04/ Laporan-BSNP2010.pdf on 07 September 2018.

Ghaliyah, S., Bakri, F., \& Siswoyo, S. (2015, October). Pengembangan modul elektronik berbasis model learning cycle $7 E$ pada pokok bahasan fluida dinamik untuk siswa SMA kelas XI [Development of an electronic module based on the 7E learning cycle model on the subject of dynamic fluids for XI grade high school students]. In Prosiding Seminar Nasional Fisika (Vol. 4, pp. SNF2015-II).

Gonzalez, H.B. \& Kuenzi, J. J. (2012). Science, technology, engineering, and mathematics (STEM) education: A Primer. Congressional Research Service.

Hake, R. R. (2002, August). Relationship of individual student normalized learning gains in mechanics with gender, high-school physics, and pretest scores on mathematics and spatial visualization. In Physics education research conference (Vol. 8, No. 1, pp. 1-14).

Hannover Research. (2011) Successful K-12 STEM education: Identifying effective approaches in science, technology, engineering, and mathematics. National Academies Press. NW, Suite 300, P 202.756.2971 F 866.808.6585]. Washington, DC: U.S.

Howe, C., McWilliams, D., \& Cross, G. (2005). Chance favours the prepared mind: Incubation and the delayed effects of peer collaboration. British Journal of Psychology, 97, 67-93

Karanggulimu, L., Sudjito, D. N., \& Noviandini, D. (2017). Desain modul praktikum mandiri tentang gerak parabola menggunakan simulasi [Design of independent practicum module about parabolic motion using simulation]. PhET" Projectile Motion". In Prosiding Seminar Nasional \& Internasional.

Knight, J. K., Wise, S. B., \& Southard, K. M. (2013). Understanding clicker discussions: Student reasoning and the impact of instructional cues. CBE-Life Sciences Education, 12(4), 645-654

Loverude, M. E., Kautz, C. H., \& Heron, P. R. (2003). Helping students develop an understanding of Archimedes' principle. I. Research on student understanding. American Journal of Physics, 71(11), 1178-1187

Nurmayanti, F., Bakri, F., \& Budi, E. (2015). Pengembangan modul elektronik fisika dengan strategi PDEODE pada pokok bahasan teori kinetik gas untuk siswa kelas 
XI SMA [Development of Electronic Physics Module with PDEODE Strategy on the Subject of Gas Kinetic Theory for Class XI High School Students]. Prosiding Simposium Nasional Inovasi dan Pembelajaran Sains, 2015, 337.

Oktaria, D. (2015). Refleksi diri sebagai salah satu metode pembelajaran di Fakultas Kedokteran. Lampung: FK Universitas lampung [Self-reflection as one of the learning methods in the Faculty of Medicine. Lampung: FK, University of Lampung].

Osborne, J., \& Patterson, A. (2011). Scientific argument and explanation: A necessary distinction? Science Education, 95(4), 627-638.

Risca, A. \& Nadi, S. (2014). Pengaruh model pembelajaran guided inquiry berbasis eksperimen terhadap keterampilan berfikir kritis siswa pada materi fluida statis di SMA Negeri 1 Gedangan [The effect of experimental-based guided inquiry learning model on students' critical thinking skills on static fluid material in SMA Negeri 1 Gedangan]. Jurnal Inovasi Pendidikan Fisika. 3(2). 167-173.

Saleta, M. E., Tobia, D., \& Gil, S. (2005). Experimental study of Bernoulli's equation with losses. American journal of physics, 73(7), 598-602.

Setiadi, R., \& Muflika, A. A. (2012). Eksplorasi pemberdayaan courseware simulasi PhET untuk membangun keterampilan proses sains siswa SMA [Explore the empowerment of PhET simulation courseware to build high school students' science process skills]. Jurnal Pengajaran MIPA, 17(2), 258-268.

Simon, S., \& Richardson, K. (2009). Argumentation in school science: Breaking the tradition of authoritative exposition through a pedagogy that promotes discussion and reasoning. Argumentation, 23(4), 469.

Sugianto, D., Abdullah, A. G., Elvyanti, S., \& Muladi, Y. (2013). Modul virtual: Multimedia flipbook dasar teknik digital [Virtual module: Multimedia flipbook, basic digital technique]. Innovation of Vocational Technology Education, 9(2).

Suyatna, A., Maulina, H., Rakhmawati, I., \& Khasanah, R. A. N. (2018). Electronic versus printed book: A comparison study on the effectivity of senior high school physics book. Jurnal Pendidikan IPA Indonesia, 7(4), 391-398.

Syukri, M., Halim, L., \& Meerah, T. S. M. (2013, March). Pendidikan STEM dalam entrepreneurial science thinking 'ESciT': Satu perkongsian pengalaman dari UKM untuk ACEH [STEM Education in Entrepreneurial Science Thinking 'ESciT': A Collaboration of Experiences from SMEs for ACEH]. In Aceh Development International Conference (pp. 26-28)..

Task Force STEM (2014). Innovate: A blueprint for science, technology, engineering, and mathematics in California public education. Dublin, CA: Californians Dedictaed to Education Foundation.

Tatli, Z., \& Ayas, A. (2013). Effect of a virtual chemistry laboratory on students' achievement. Journal of Educational Technology \& Society, 16(1), 159-170.

Tatli, Z., \& Ayas, A. (2013). Effect of a virtual chemistry laboratory on students' achievement. Journal of Educational Technology \& Society, 16(1), 159-170.

Wang, H., Moore, T. J., Roehrig, G. H., \& Park, M. S. (2011). STEM integration: teacher perceptions and practice. Journal of Pre-College Engineering Education Research, 1(2), 1-13. doi:10.5703/1288284314636. 